\author{
LESZEK KUŹNICKI \\ Instytut Biologii Doświadczalnej im. M. Nenckiego PAN \\ Pasteura 3, 02-093 Warszawa \\ E-mail: l.kuznicki@nencki.gov.pl
}

\title{
BADANIA NAD RUCHEM PIERWOTNIAKÓW W INSTYTUCIE IM. MARCELEGO NENCKIEGO
}

\section{JAN DEMBOWSKI, JEGO UCZNIOWIE I NASTEPCY}

Ruch jest jednym $z$ podstawowych przejawów życia. Od pierwszych lat istnienia Instytutu im. Marcelego Nenckiego po współczesność, był on badany u pierwotniaków, zwierzat i ludzi pod różnymi aspektami.

W 1922 r. po polsku, a w 1923 r. po niemiecku ukazały sie publikacje dotyczące ruchu Paramecium caudatum w naczynkach o różnym kształcie geometrycznym autorstwa Jana Dembowskiego. W środowiskach pozbawionych pokarmu (w czystej wodzie) orzęsek zachowuje stały kierunek ruchu, a natrafiajac na stałą przeszkodę odbija się pod stałym katem (około $70^{\circ}$ ). W opinii Dembowskiego jest to utrwalona reakcja przystosowawcza, pozwalajaca orzęskowi wypłynąc ze środowiska pozbawionego pokarmu (bakterii). W środowisku $z$ bakteriami orzęski zatrzymuja się przy ściankach naczyń i żeruja.

Kolejne prace Jana Dembowskiego nad $P$. caudatum (łącznie sześć publikacji $z$ lat 1928-1931) dotyczyły wyjaśnienia mechanizmu ujemnej geotaksji orzęsków. Na tym tle powstał spór między Janem Dembowskim a Otto Kohlerem.

Pierwszy postulował, że orientacja góra-dół orzęska wynika $z$ jego budowy - przesunięcia środka ciężkości ku tyłowi, drugi twierdził, że wodniczki pokarmowe i inne elementy występujace w cytoplazmie Paramecium pełnia funkcję statocyst. Po latach okazało się, że mechanizm geotaksji ujemnej orzęsków jest bardziej złożony.

Jan Dembowski był przede wszystkim etologiem. W tej dziedzinie koncentrował się na problematyce plastyczności instynktu. Zjawiska badał eksperymentalnie wykorzy- stując larwy chruścika Molanna angustata. W przyrodzie larwy tych zwierząt żyja na obrzeżach jezior i innych zbiorników wodnych, budując domki $\mathrm{z}$ piasku, w których przebywaja do czasu przepoczwarzenia się w owada. Dembowski wykazał, że chruściki w warunkach eksperymentalnych moga budować domki $z$ innych niż piasek materiałów. Zmieniaja też sposób budowy, kiedy $\mathrm{w}$ następstwie amputacji nie maja wszystkich nóg, za każdym razem powstaje domek umożliwiajacy normalne funkcjonowanie zwierzęcia.

W 1934 r. Jan Dembowski został powolany na stanowisko profesora nadzwyczajnego na Uniwersytecie Stefana Batorego w Wilnie. Po II wojnie światowej podją działalność badawcza w kraju w 1947 r. w Łodzi, a od 1953 r. w Warszawie, w nowo wybudowanej siedzibie Instytutu Nenckiego w Warszawie przy ulicy Pasteura 3. Już w latach 19471953 stworzył liczna grupe uczniów, która podażała $\mathrm{w}$ badaniach $\mathrm{w}$ dwóch kierunkach: fizjologii pierwotniaków i etologii owadów. Po śmierci Jana Dembowskiego etolodzy zostali przeniesieni do Zakładu Neurofizjologii, protozoolodzy prowadzili badania w Zakładzie Biologii Komórki. Dominowały prace nad różnymi przejawami ruchu, które prowadzono na orzęskach, amebach i wiciowcach. $Z$ tego zakresu w latach 1951-2017 obroniono 27 doktoratów (Tabela 1).

W XXI w. pierwotniaki stały się mniej popularnym obiektem badań $\mathrm{w}$ porównaniu $z$ wiekiem XX. Ten stan rzeczy odzwierciedlaja różne zmiany, jakie nastapily w Instytucie im. Marcelego Nenckiego. Aktualnie badania na modelu orzęsków prowadzone 
Tabela 1. Wykaz osób, które w latach 1951-2017 uzyskały stopień doktora na podstawie badań ruchu u pierwotniaków, prowadzonych w Instytucie Nenckiego.

\begin{tabular}{|c|c|c|c|}
\hline Rok & Imię i nazwisko & Tytuł rozprawy & Promotor \\
\hline 1951 & Stanisław Dryl & $\begin{array}{l}\text { Chemotropizm Paramecium caudatum w zależności od zmian } \\
\text { chemicznych środowiska }\end{array}$ & J. Dembowski \\
\hline 1958 & $\begin{array}{l}\text { Włodzimierz Kinastow- } \\
\text { ski }\end{array}$ & $\begin{array}{l}\text { Analiza wpływu bodźców mechanicznych na kurczliwość Spiro- } \\
\text { stonum ambiguum Ehrbg }\end{array}$ & J. Dembowski \\
\hline 1962 & Leszek Kuźnicki & $\begin{array}{l}\text { Badania nad odwracalna immobilizacja Paramecium caudatum } \\
\text { wywołaną przez niektóre narkotyki i sole nieorganiczne }\end{array}$ & J. Dembowski \\
\hline 1965 & Maria Brutkowska & $\begin{array}{l}\text { Wpływ pH kationów oraz czynników zaburzających koordynację } \\
\text { ruchu rzęskowego na fagocytozę w Paramecium }\end{array}$ & S. Dryl \\
\hline 1970 & $\begin{array}{l}\text { Danuta Pietrowicz- } \\
\text { Kosmynka }\end{array}$ & Chemotaksja u Sentor coeruleus & S. Dryl \\
\hline 1972 & Ewa Mikołajczyk & Analiza ruchów euglenoidalnych u Euglena gracilis & L. Kuźnicki \\
\hline 1973 & Barbara Hrebenda & $\begin{array}{l}\text { Rola wapnia zewnętrznego w reakcjach lokomotorycznych Amo- } \\
\text { eba proteus }\end{array}$ & L. Kuźnicki \\
\hline 1974 & $\begin{array}{l}\text { Irena Totwen- } \\
\text { Nowakowska }\end{array}$ & $\begin{array}{l}\text { Badania nad budową i reaktywnościa ruchowa form podwójnych } \\
\text { Stylonychia mytilus (O.F.M.) }\end{array}$ & S. Dryl \\
\hline 1975 & Stanisław Fabczak & $\begin{array}{l}\text { Pobudliwość i kinetyka cyklu skurczowo-rozkurczowego u Spiro- } \\
\text { stomum ambiguum }\end{array}$ & L. Kuźnicki \\
\hline 1976 & Barbara Tołłoczko & Mechanizmy endocytozy u Paramecium caudatum & L. Kuźnicki \\
\hline 1977 & Zbigniew Baranowski & $\begin{array}{l}\text { Integracja zjawisk skurczowych w plazmodium Physarum polyce- } \\
\text { phalum }\end{array}$ & L. Kuźnicki \\
\hline 1977 & Michał Opas & Analiza zjawisk skurczowych u Amoeba proteus & L. Kuźnicki \\
\hline 1978 & Małgorzata Cieślawska & $\begin{array}{l}\text { Aktywność skurczowa różnych obszarów plazmodium i jej roz- } \\
\text { kład w czasie i przestrzeni }\end{array}$ & A. Grębecki \\
\hline 1979 & Mariola Moczoń & $\begin{array}{l}\text { Współzależność różnych składowych skurczu oraz przepływu } \\
\text { protoplazmy w krótkich odcinkach żył plazmodium Physarum } \\
\text { polycephalum }\end{array}$ & A. Grębecki \\
\hline 1979 & Jacek Kurdybacha & $\begin{array}{l}\text { Wpływ zmiennego stężenia jonów Ca2+ w środowisku otaczają- } \\
\text { cym na reakcję orzęsków (Paramecium, Stylonychia) stymulowane } \\
\text { bodźcami o różnej modalności }\end{array}$ & S. Dryl \\
\hline 1982 & Wanda Kłopocka & Współzależności ruchowe różnych okolic ciała Amoeba proteus & A. Grębecki \\
\hline 1982 & Andrzej Kubalski & Podłoże jonowe pobudliwości u orzęska morskiego Fabrea salina & S. Dryl \\
\hline 1982 & $\begin{array}{l}\text { Hanna Szydłowska- } \\
\text {-Fabczak }\end{array}$ & $\begin{array}{l}\text { Badania nad fizjologiczna rola cholesterolu i stigmasterolu w } \\
\text { błonie komórkowej Paramecium octaurelia }\end{array}$ & S. Dryl \\
\hline 1983 & Anna Wasik & $\begin{array}{l}\text { Wpływ czasteczek zawiesiny na fagocytozę i dynamike strumie- } \\
\text { nia cytoplazmatycznego u Paramecium bursaria }\end{array}$ & J. Sikora \\
\hline 1983 & Joanna Kołodziejczyk & $\begin{array}{l}\text { Współzależności skurczu i przepływu protoplazmy w różnych } \\
\text { okolicach plazmodium Physarum polycephalum }\end{array}$ & A. Grębecki \\
\hline 1988 & Krzysztof Łazowski & Reakcje fotonowe i fototaksje A. proteus & L. Kuźnicki \\
\hline 1998 & Paweł Pomorski & $\begin{array}{l}\text { Zwiazki jądra komórkowego Amoeba proteus z jej cytoszkieletem } \\
\text { i ruchliwością }\end{array}$ & L. Grębecka \\
\hline 2001 & Mirosława Walerczyk & $\begin{array}{l}\text { Mechanizm reakcji fotofobowej u Stentor coeruleus - rola cy- } \\
\text { klicznego GMP }\end{array}$ & S. Fabczak \\
\hline 2008 & Katarzyna Sobierajska & $\begin{array}{l}\text { Fosducyna - regulator aktywności białek G w przekazywaniu } \\
\text { bodźców świetlnych u Blepharisma japonicum. }\end{array}$ & S. Fabczak \\
\hline 2011 & Cezary Bregier & $\begin{array}{l}\text { Rola białek podobnych do fosducyny w fałdowaniu tubuliny i } \\
\text { organizacji mikrotubul u Tetrahymena thermophila }\end{array}$ & H. Fabczak \\
\hline 2017 & Ewa Wacławek & $\begin{array}{l}\text { Analiza funkcjonalna białek tnacych mikrotubule w komorkach } \\
\text { orzęska Tetrahymena thermophila }\end{array}$ & D. Włoga, \\
\hline 2017 & Paulina Urbańska & $\begin{array}{l}\text { Lokalizacja i funkcja białek FAP61, FAP251 i FAP43 w rzęskach } \\
\text { Tetrahymena thermophila }\end{array}$ & D. Włoga \\
\hline
\end{tabular}


sa tylko w Pracowni Cytoszkieletu i Biologii Rzęsek, która od 2015 r. kieruje Dorota Włoga. Szczegółowe informacje i komentarze dotyczace prowadzonych w Polsce badań protozoologicznych znajduja się w czteroto- mowym wydawnictwie $z$ roku 2007 i 2008 "Instytut Biologii Doświadczalnej im. M. Nenckiego", 2007 i 2008 oraz Leszek Kuźnicki - „Protozoologia w Polsce”, 2003. 